\title{
Japanese Bankruptcy Reform And The Implications Of The Civil Rehabilitation Act
}

\author{
Gregory R. Stone, University of Nevada, Reno, USA
}

\begin{abstract}
In April of 2000, the Japanese Diet instituted two changes to their bankruptcy code in an attempt to address perceived weaknesses. The first change was the elimination of Composition, the most popular form of bankruptcy reorganization at that time. The second was the introduction of the Civil Rehabilitation Act. One of the primary goals of the introduction of Rehabilitation was to induce managers of distressed firms to file sooner when the firm's financial problems were less difficult to address. This paper examines the impact of the Civil Rehabilitation Act and finds that after the Act was implemented larger firms make better candidates for reorganization but smaller firms are in poorer financial condition and are hence, poorer candidates for reorganization.
\end{abstract}

Keywords: Bankruptcy, Civil Rehabilitation, Corporate Reorganization, Composition, Japan

\section{INTRODUCTION}

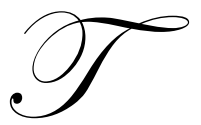

he failure of non-viable firms, though unpleasant for the parties involved, is critical to a country's long-term industrial growth and health. Without failure, less efficient firms continue to employ resources that would be better allocated to more productive end uses and create a drag on the economy as a whole. Schumpeter (1942) refers to the positive aspects of failure as "creative destruction." A country's bankruptcy system is therefore a critical component in the way an economy allocates resources. The process is a dynamic one in which troubled firms sell off assets in an attempt to stave of default while the particular asset sold can either enhance or diminish the firm's long term economic viability.

In an attempt to address the economic malaise of the country's "post-bubble" economy, the Japanese Diet adopted the Civil Rehabilitation Act ("Rehabilitation") in December 1999. Rehabilitation replaced the Composition Act ("Composition) with the intention of addressing some of the perceived weaknesses of the old bankruptcy system. ${ }^{1}$ Prior to the introduction of Rehabilitation, the Japanese bankruptcy system consisted of three forms of bankruptcy reorganization, Composition, Corporate Reorganization ("Reorganization") and Corporate Arrangement ("Arrangement"). ${ }^{2}$ The three reorganization methods each had unique characteristics and were highly dissimilar. In particular, Composition differed dramatically from Reorganization. Composition was intended for small firms while Reorganization was intended for large firms. Xu (2004) finds that Composition filings were rare for large firms for the following reasons: (i) firms filing under Composition had to submit a reorganization plan at the time of filing; (ii) firms were not granted a stay against creditors; (iii) firms could only file if they defaulted on a debt payment and were therefore already in significant financial distress at the time of filing.

From the perspective of management, the most critical difference between the different forms of bankruptcy was that if a firm filed under the Reorganization law, a court appointed trustee was chosen to replace management and operate the firm. ${ }^{3}$ Hence, managers were simultaneously filing bankruptcy and terminating their own employment, creating a strong incentive to delay filing (see Adler et al. (2005)). Composition, which was intended for small firms, had no such stipulation, due to the impracticality of finding trustees for every small business which failed. Rehabilitation fell somewhere between these two extremes, allowing the court to appoint a trustee, but not requiring it. From management's perspective, this made the Rehabilitation less desirable than Composition, but more desirable than Reorganization. As a replacement for Composition, Rehabilitation was also intended for small firms however, the new law put no explicit restriction on the size of firms which could use it. 
With the introduction of Rehabilitation, the agency dynamics of the available reorganization proceedings shifted dramatically as managers were no longer automatically dismissed when they filed.

Because Rehabilitation did not require the replacement of management, managers preferred it to the Reorganization and it became the de facto form of bankruptcy reorganization for both small and large firms. Within two years of its enactment, large firms had completely stopped filing under the Reorganization law. In this paper, I show that the impact of the new law is dependent upon the size of the filing firm. Smaller firms are in worse financial condition when they file, experiencing a greater decline in assets over the three years prior to filing, having poorer operating earnings prior to filing and therefore making poorer candidates for reorganization. Larger firms, though also undergoing a greater decline in the value of assets prior to filing are more profitable, suggesting that they make better candidates for reorganization and that the introduction of Civil Rehabilitation improved the bankruptcy system for large firms. Such results can occur if management, no longer automatically replaced, takes a longer term perspective on the firm and sells off less profitable or less important assets.

In this paper I provide general information on the Japanese bankruptcy system and examine the impact the introduction of Rehabilitation had on the financial condition of the firms filing for reorganization. The rest of this paper is organized as follows: the next section is a literature review; the section that follows describes the data, hypotheses and methodology. The subsequent section discusses the results and the final section concludes the paper.

\section{LITERATURE REVIEW AND JAPANESE BANKRUPTCY BACKGROUND INFORMATION}

\section{Background Information on the Japanese Bankruptcy System}

Japan has five forms of bankruptcy, three forms of reorganization and two forms of liquidation. Of the three current forms of reorganization, both Rehabilitation and Corporate Arrangement allow management to remain in charge of the firm. Reorganization requires that a court appointed trustee take over the firm's operations.

Prior to the introduction of Rehabilitation, Composition was the most popular bankruptcy reorganization procedure. Eisenberg and Tagashira (1994) find that three quarters of all reorganization cases are Composition cases. Despite the desirability from management's perspective, the proceeding was considered imperfect for several reasons. In particular, the court's supervision of the process terminated when the plan was confirmed rather than when the debtor had fulfilled its obligations under the plan and Composition did not provide for a supervising authority to be appointed by the court. Hence, if the debtor chose not to fulfill one or more of its obligations, the creditor had no means of enforcing the plan. ${ }^{4}$ From the perspective of management, Composition was the desirable form of bankruptcy as it allowed management to remain in charge of the firm and imposed no court enforcement after plan confirmation.

Reorganization was intended for large firms. It placed an automatic stay on creditors to keep them from claiming their collateral, and unlike Composition, a reorganization plan did not need to be filed at the time of the bankruptcy filing. This allowed firms with multiple creditors time to come to an agreement on a reorganization plan. Reorganization also required that management be replaced by a court appointed trustee upon filing making it less desirable than Rehabilitation from the perspective of management.

\section{Literature Review}

Multiple authors have examined the US bankruptcy laws and suggested that the system is overly prodebtor. Bradley and Rosenzweig (1992) find that Chapter 11 reduces social welfare and that stockholders and bondholders recovered less after the Bankruptcy Reform Act of 1978 replaced the Chandler Act, a major reform to the US bankruptcy system and that the main beneficiaries of the change are managers. Bradley and Rosenzweig's finding suggest that even well intentioned changes may have unintended results. Bebchuk and Chang (1992) examine the US bankruptcy bargaining process and show that bankruptcy rules empower managers, in particular through the rule of exclusivity. Altman (1993) supports this position suggesting that the Chapter 11 process is troubled and should be revised. 
Bankruptcy is a stigmatizing and personally costly event for management (see e.g. Gilson and Vetsuypens (1993), Hotchkiss (1995), Khanna and Poulsen (1995)). Thus a bankruptcy system which imposes relatively greater personal costs on management will likely results in managers delaying filing relatively longer and greater destruction of firm value (see e.g. Mooradian (1994), White (1994), Adler et al. (2005), Bris (2006)). One of the principle arguments made in favor of debtor in possession (DIP) protections is that DIP protections result in decreased incentives for management to delay filing, and hence less destruction of firm value occurs than would have occurred if those protections were not in place (see e.g. Gertner and Scharfstein (1991), Mooradian (1994), Berkovitch et. al. (1998), Adler et al. (2005)).

Bankruptcy in Japan differs greatly from bankruptcy in the US, not only because of the different legal statutes, but also because of the Japanese main bank system and cross shareholding. Main banks frequently have equity stakes and managerial ties to borrowing firms. Morck and Nakamura (1999) find that up to two-thirds of a firm's equity may be held by banks and other firms and Sheard (1994) finds that main banks are typically major shareholders in the firm to which they lend and that main banks are one of the five largest shareholders' in seventytwo percent of firms listed on the Tokyo Stock Exchange. ${ }^{5}$ Ostensibly, the holding of both debt and equity reduces creditor conflicts. Prowse (1992) finds that the corporate governance systems of keiretsu firms are different than the governance systems in non-keiretsu firms and the relationship between managers and keiretsus reduce information asymmetries and allow for improved monitoring. Prowse also finds that the bank's dual role as creditor and shareholder limit their incentives to advance shareholder interests. Kang and Shivdasani (1995) and Kaplan and Minton (1994) find increased management turnover following bank appointments to boards, consistent with the idea that main banks monitor client firms. Hoshi et al. (1990) find that Japanese firms have a reduced cost of financial distress and that leverage increases the chance that firm will encounter cash flow difficulties. The authors show that financial distress effects the firm's investment decisions and performance and that distressed firms with close banking relationships invest and sell more than firms without close banking relationships. They also find that nonkeiretsu firms undergo significant downsizing following banker appointments but that main bank firms do not, consistent with the position that banks support weak main bank group firms.

Reliance on formalized bankruptcy procedures increases both the direct and indirect costs of bankruptcy and is more inefficient (see e.g. Jensen (1989), Wruck (1990), Helwege (1999)). Since main banks often hold both debt and equity positions, bankruptcy negotiations may be less contentious resulting in a more efficient reorganization (see e.g. Prowse (1990), Hoshi et al. (1990), Aoki and Patrick (1994), Berlin et al. (1996)). Sheard (1994) suggests that keiretsu banks are able to manage both firm liquidations and reorganizations without court involvement while Suzuki and Wright (1985) find that main banks screen firms for their suitability for reorganization. Adler et al. (2005) finds that a change in the US system which deprived debtors of power over the reorganization resulted in firms delaying filing. Khanna and Poulsen (1995) find that the managers of distressed firms make decisions which are similar to managers at non-distressed firms. This position is supported by other bankruptcy studies such as Lang and Stulz (1992) and Denis and Denis (1995) which find that factors outside the firm's control are important causes of bankruptcy. Hence, DIP protections result in both less resistance to filing by management and the manager's superior knowledge of the problems faced by the firm to be used and potentially less disruptive reorganization process (see e.g. Gertner and Scharfstein (1991), Mooradian (1994), White (1994), Berkovitch et al. (1998)). ${ }^{6}$

Given the greater efficiency and decreased expense when no court is involved, and with insider knowledge of the firm's problems due to the main bank's monitoring of operations, the issue of why Japanese firms file formal bankruptcy is raised. Sheard (1994) suggests that large firms are less likely to use the court and more likely to be keiretsu firms while Helwege and Packer (2003) suggest that relationships with a main bank increase the likelihood that the distressed firm will end up in liquidation. Easterbrook (1990) suggests that creditors resort to formalized bankruptcy when the legal process is superior to the market process. 


\section{DATA, HYPOTHESES, AND METHODOLOGY}

\section{Data and Methodology}

The data used in this study comes from the Teoikuku data bank and the PACAP Japanese database from the Pacific-Basin Capital Market Research Center at the University of Rhode Island. The data set used in this paper includes 60 bankruptcy filings. The data set is divided into "Large Firm" and "Small Firm" subgroups based on the size of the firm's assets as reported in the firm's final annual report. The subgroups divide each form of filing, Reorganization or Rehabilitation, in half and compare the forms of filing within the smaller group and the larger group separately. Industry adjusted operating earnings are calculated using PACAP's 3 digit industry IDs.

Table 1 shows the 60 bankruptcy filings by type and industry. Thirty-two are Rehabilitation filings while 28 are Reorganization filings. There are 333 digit industry codes in the PACAP Japan data set. Filing firms are from 17 of those 33 industries and are listed in the far left column. The industries are ranked in descending order from the industry with the largest percentage of filings to the smallest as a percentage of all bankruptcies. As can be seen, the Construction industry, Machinery industry and Retail industry had the most filings with those 3 industries making up nearly $50 \%$ of all filings.

\begin{tabular}{lrrrr}
\multicolumn{4}{c}{ Table 1: Filings by Industry Type } \\
$\begin{array}{c}\text { Corporate } \\
\text { Reorganization }\end{array}$ & $\begin{array}{c}\text { Civil } \\
\text { Rehabilitation }\end{array}$ & Total & Percent \\
Industry & 4 & 9 & 13 & $22 \%$ \\
\hline Construction & 2 & 6 & 8 & $13 \%$ \\
Machinery & 5 & 2 & 7 & $12 \%$ \\
Retail & 2 & 4 & 6 & $10 \%$ \\
Electric Machinery & 0 & 4 & 4 & $7 \%$ \\
Textiles & 2 & 1 & 3 & $5 \%$ \\
Wholesale & 1 & 2 & 3 & $5 \%$ \\
Real Estate & 2 & 1 & 3 & $5 \%$ \\
Services & 2 & 0 & 2 & $3 \%$ \\
Chemicals & 2 & 0 & 2 & $3 \%$ \\
Glass And Ceramics & 1 & 1 & 2 & $3 \%$ \\
Iron And Steel & 1 & 1 & 2 & $3 \%$ \\
Metal Products & 1 & 0 & 1 & $2 \%$ \\
Fishery & 1 & 0 & 1 & $2 \%$ \\
Transportation Equipment & 0 & 1 & 1 & $2 \%$ \\
Financial* & 1 & 0 & 1 & $2 \%$ \\
Shipping & 1 & 0 & 1 & $2 \%$ \\
Warehousing And Wharfing & 28 & 32 & 60 & $100 \%$ \\
\hline Total & & &
\end{tabular}

\section{EMPIRICAL RESULTS}

\section{Firm Characteristics and Type of Bankruptcy}

Figure 1 shows a distinctive trend which appears when examining bankruptcy filings by type over time. In years $2000,2001,2002$, and 2003, Reorganization filings dropped from $57 \%$ to $25 \%$ to $7 \%$ to $0 \%$ an indication of the decline in desirability of the Reorganization Law once Rehabilitation was introduced. Firms also stopped filing under the Liquidation Law as well. By 2003, firms began filing solely under the Rehabilitation Law. 


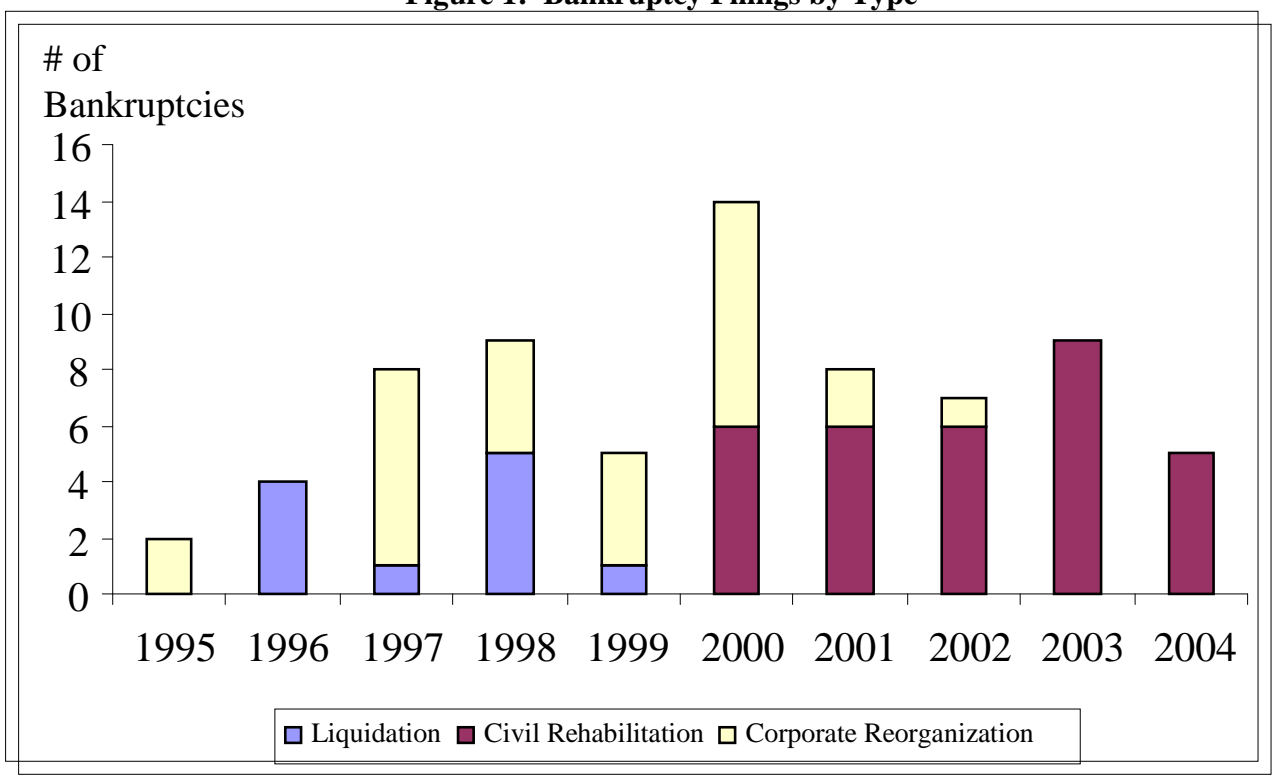

Panel A examines the relationship statistically and shows that firms were significantly more likely to liquidate in the 1995-1999 period - prior to the introduction of Rehabilitation - than during the 2000-2004 period when Rehabilitation was available.

\begin{tabular}{|c|c|c|c|}
\multicolumn{1}{c|}{} & \multicolumn{2}{c|}{ Panel A } & Total \\
\cline { 2 - 4 } \multicolumn{1}{c|}{} & Liquidation & Reorganization & 28 \\
\hline $\mathbf{1 9 9 5 - 1 9 9 9}$ & 8 & 17 & 43 \\
\hline To00-2004 & 0 & 43 & 71 \\
\hline
\end{tabular}

Chi-square $=15.26$

$p$-value is less than 0.001

\section{Univariate Analysis}

To examine the impact of the new bankruptcy laws, differences in firms filing Reorganization and Rehabilitation are compared statistically. Univariate analysis reveals substantial differences between the firms filing under the two forms of reorganization. Table 2 displays the results in each of three main areas: Size, Capital Structure, and Profitability.

Measures of size (Assets, Sales, Liabilities) uniformly suggest that the typical Rehabilitation firm is smaller. Larger firms have economies of scale in the administrative and legal expenses encountered in bankruptcy though this may or may not be offset by a more contentious creditor negotiation process. While the size of the firm is important, it does not seem plausible that the enactment of Rehabilitation caused there to be fewer large bankruptcies. Rather, the smaller size of the filing firms may reflect Rehabilitation replacing Composition, under which small firms had been filing. 
Table 2: Summary Statistics

Assets (millions of $¥$ )

Sales (millions of $¥$ )

Liabilities (millions of $¥$ )

\begin{tabular}{|c|c|c|c|c|c|c|c|c|}
\hline \\
\hline \multicolumn{3}{|c|}{ Mean } & \multicolumn{3}{|c|}{ Median } & \multicolumn{3}{|c|}{ Standard Deviation } \\
\hline Reorg & Rehab & $p$-value & Reorg & Rehab & $p$-value & Reorg & Rehab & $p$-value \\
\hline 196,386 & 60,002 & $(0.033)$ & 113,864 & 25,506 & $(0.035)$ & 311,464 & 89,444 & $(0.000)$ \\
\hline 163,143 & 44,172 & $(0.022)$ & 58,085 & 16,079 & $(0.039)$ & 253,112 & 69,835 & $(0.000)$ \\
\hline 167,495 & 66,036 & $(0.068)$ & 64,385 & 26,131 & $(0.082)$ & 269,127 & 97,185 & $(0.000)$ \\
\hline
\end{tabular}

Liabilities to Assets
Working Capital to Assets
Current Ratio
Equity Held by Financial Institutions
Retained Earnings
Change in Assets (Year -3 to -1 )

\begin{tabular}{rrr}
\multicolumn{3}{c}{ Mean } \\
\hline Reorg & Rehab & $p$-value \\
0.78 & 1.22 & $(0.053)$ \\
-0.04 & -0.51 & $(0.036)$ \\
1.11 & 0.82 & $(0.148)$ \\
$27.0 \%$ & $19.8 \%$ & $(0.055)$ \\
2,941 & $-19,892$ & $(0.039)$ \\
$2 \%$ & $-22 \%$ & $(0.000)$
\end{tabular}

Capital Structure

\begin{tabular}{rrrrrrrr}
\multicolumn{3}{c}{ Median } & & \multicolumn{3}{c}{ Standard Deviation } \\
\cline { 1 - 4 } \cline { 5 - 7 } Reorg & Rehab & $p$-value & & Reorg & Rehab & $p$-value \\
0.88 & 0.92 & $(0.166)$ & & 0.24 & 1.19 & $(0.000)$ \\
-0.02 & -0.19 & $(0.031)$ & & 0.28 & 1.18 & $(0.000)$ \\
0.96 & 0.70 & $(0.096)$ & & 0.92 & 0.56 & $(0.008)$ \\
$29.7 \%$ & $19.8 \%$ & $(0.017)$ & & $14.5 \%$ & $11.5 \%$ & $(0.256)$ \\
353 & $-3,411$ & $(0.012)$ & & 21,890 & 55,915 & $(0.000)$ \\
$-2 \%$ & $-14 \%$ & $(0.001)$ & & 0.20 & 0.29 & $(0.052)$
\end{tabular}

\begin{tabular}{rrr}
\multicolumn{3}{c}{ Mean } \\
\hline Reorg & Rehab & $p$-value \\
$-2.1 \%$ & $-70.0 \%$ & $(0.084)$ \\
$1.3 \%$ & $-3.9 \%$ & $(0.004)$ \\
$1.1 \%$ & $-10.4 \%$ & $(0.066)$ \\
$25 \%$ & $56 \%$ & \\
$50 \%$ & $75 \%$ &
\end{tabular}

\begin{tabular}{ccc}
\multicolumn{3}{c}{ Profitability } \\
Median \\
\hline Reorg & Rehab & $p$-value \\
$-0.1 \%$ & $-10.3 \%$ & $(0.001)$ \\
$1.3 \%$ & $-0.6 \%$ & $(0.009)$ \\
$0.9 \%$ & $-0.6 \%$ & $(0.009)$
\end{tabular}

Standard Deviation

\begin{tabular}{rrr} 
Reorg & \multicolumn{1}{c}{ Rehab } & $p$-value \\
$7.0 \%$ & $214.9 \%$ & $(0.000)$ \\
$4.5 \%$ & $8.6 \%$ & $(0.001)$ \\
$3.4 \%$ & $34.1 \%$ & $(0.000)$
\end{tabular}

Operating Earnings to Liabilities

Operating Earnings to Assets (Ind Adj)

Negative Operating Earnings

Negative Net Income

$50 \% \quad 75 \%$

t-test reported for averages, Wilcoxon Rank Sum Test reported for medians, F-test reported for standard deviations, p-values reported in parentheses. $* * *, * *$, and $*$ indicate that the parameter estimate is significantly different from 0 at the $1 \%, 5 \%$, and $10 \%$ level, respectively.

Capital structure statistics (Liabilities to Assets, Working Capital to Total Assets, Current Ratio, Equity Held by Financial Institutions, Retained Earnings, Change in Assets from years -3 to -1 ) indicate that firms filing Rehabilitation did not have leverage ratios significantly greater than those filing Reorganization, though they are on average larger. Firms filing Rehabilitation did have less working capital as a percentage of assets, a lower current ratio, less equity held by financial institutions, had smaller retained earnings and had a larger decline in the value of assets in the three years prior to filing. All of these statistics present the image of firms in greater financial distress filing under the Rehabilitation Act. The greater decline in assets initially suggests that firms which filed under the Rehabilitation law are trying to stave off bankruptcy more than firms which filed Reorganization. This issue will be examined in more depth in a future section of this paper when firms are partitioned into large firms and small firms and when a regression analysis is conducted. Also of interest, smaller firms had weaker relationships with main banks, than did larger firms, as indicated by the smaller percentage of shares held by financial institutions. The greater equity held by financial institutions proxies for the more control the main bank exerts over the distressed firm and also the closeness of the bank's monitoring process.

The third area examined is profitability (Net Income to Assets, Operating Earnings to Liabilities, Operating Earnings to Assets, Percent with Negative Operating Earnings, Percent with Negative Net Income). Since they are free from the influences of capital structure and interest expense, operating earnings (EBIT/Assets, EBIT/Liabilities) are an indication of the "going value" of the firm, and hence give better insight into the potential success of the firm post-emergence. Firms which do not have operational profitability face substantially greater troubles than firms which are operationally profitable but which have too much debt. In all cases, the profitability of firms filing Rehabilitation is poorer than those filing Reorganization. Such a finding is indicative of firms which face greater obstacles choosing to file under the Rehabilitation Act.

Another statistic which offers a useful insight is the standard deviations of the filing firms. Again the majority of the statistics are significant indicating a large disparity between the two forms of reorganization. ${ }^{7}$ In the areas of capital structure and profitability, with the exception of the percentage of shares owned by financial 
institutions, all Rehabilitation statistics are greater than Reorganization statistics indicating that the firms using Rehabilitation are more diverse.

An additional metric from which to examine financial distress is the percentage of firms which had negative operating earnings in each of the two years prior to filing. Table 3 shows the percentages of firms with negative operating earnings two years prior to filing bankruptcy. All Large firms filing Reorganization had positive earnings in the two years prior to filing. Ninety-five percent of the filing small firms had negative operating earnings two years prior to their filing. Of those, the largest percentage chose to file under the Rehabilitation Act.

Table 3: Percentage of Firms with Negative Operating Earnings in Each of the 2 years Prior to Filing

Type and Size of Filing

\begin{tabular}{|c|c|}
\hline Reorganization (Large Firms) & $0 \%$ \\
\hline Reorganization (Small Firms) & $14 \%$ \\
\hline & $6 \%$ \\
\hline Rehabilitation (Large Firms) & $56 \%$ \\
\hline Rehabilitation (Small Firms) & $75 \%$ \\
\hline & $25 \%$ \\
\hline Liquidation (Large Firms) & 2 \\
\hline Liquidation (Small Firms) & \\
\hline
\end{tabular}

\section{Univariate Analysis by Firm Size}

To examine whether the law had different impacts after accounting for differences in the size of the firm, firms from each form of bankruptcy filing were divided in half, the smallest 14 Reorganization firms and the smallest 16 Rehabilitation firms were compared (Small Firms) and the largest 14 Reorganization firms and the largest 16 Rehabilitation firms were compared (Large Firms). Table 4 displays the univariate results of this methodology.

Assets (millions of $¥$ )

Sales (millions of $¥$ )

Liabilities to Assets

Working Capital to Assets

Current Ratio

Retained Earnings

Change in Assets (Year -3 to -1 )

Net Income to Assets

Operating Earnings to Liabilities

Operating Earnings to Assets (Ind Adj)
Table 4: Summary Statistics by Firm Size

\begin{tabular}{|c|c|c|}
\hline \multicolumn{3}{|c|}{ Mean } \\
\hline Corp & Civil & $p$-value \\
\hline 29,621 & 15,138 & $(0.115)$ \\
\hline 19,071 & 12,639 & $(0.286)$ \\
\hline 0.717 & 1.208 & (0.149) \\
\hline-0.048 & -0.523 & $(0.166)$ \\
\hline 1.201 & 0.869 & $(0.340)$ \\
\hline 5,001 & $-13,205$ & $(0.038) * *$ \\
\hline$-0.5 \%$ & $-23.9 \%$ & $(0.016) * *$ \\
\hline$-2.1 \%$ & $-110.0 \%$ & $(0.141)$ \\
\hline $2.2 \%$ & $-5.9 \%$ & $(0.002)$ *** \\
\hline $1.5 \%$ & $-8.7 \%$ & $(0.002)$ *** \\
\hline
\end{tabular}

\begin{tabular}{ccc}
\multicolumn{3}{c}{ Mean } \\
\hline Corp & Civil & $p$-value \\
277,228 & 196,429 & $(0.452)$ \\
250,029 & 140,578 & $(0.222)$ \\
0.854 & 1.202 & $(0.214)$ \\
-0.041 & -0.466 & $(0.130)$ \\
1.025 & 0.777 & $(0.293)$ \\
-385 & $-24,671$ & $(0.242)$ \\
$-0.3 \%$ & $-13.3 \%$ & $(0.167)$ \\
$-1.9 \%$ & $-23.4 \%$ & $(0.162)$ \\
$0.4 \%$ & $-1.4 \%$ & $(0.469)$ \\
$0.7 \%$ & $-11.6 \%$ & $(0.320)$
\end{tabular}

\begin{tabular}{|c|c|c|}
\hline \multicolumn{3}{|c|}{$\begin{array}{c}\text { Small Firms } \\
\text { Median }\end{array}$} \\
\hline Corp & Civil & $p$-value \\
\hline 22,490 & 15,996 & $(0.275)$ \\
\hline 11,795 & 12,608 & $(0.648)$ \\
\hline 0.814 & 0.810 & $(0.226)$ \\
\hline-0.036 & -0.293 & $(0.184)$ \\
\hline 0.934 & 0.635 & $(0.311)$ \\
\hline 262 & $-4,739$ & $(0.041) * *$ \\
\hline$-3.8 \%$ & $-26.0 \%$ & $(0.020) * *$ \\
\hline$-0.5 \%$ & $-18.5 \%$ & $(0.007) * * *$ \\
\hline $0.9 \%$ & $-6.4 \%$ & $(0.007) * * *$ \\
\hline $0.7 \%$ & $-5.6 \%$ & $(0.006) * * *$ \\
\hline
\end{tabular}

\begin{tabular}{|c|c|c|}
\hline \multicolumn{3}{|c|}{ Standard Deviation } \\
\hline Corp & Civil & $p$-value \\
\hline 31,543 & 7,600 & $(0.000) * * *$ \\
\hline 20,215 & 9,156 & $(0.004) * * *$ \\
\hline 0.291 & 1.305 & $(0.000)$ *** \\
\hline 0.338 & 1.307 & $(0.000) * * *$ \\
\hline 1.119 & 0.664 & $(0.050) *$ \\
\hline 21,667 & 25,067 & $(0.603)$ \\
\hline $16.5 \%$ & $32.4 \%$ & $(0.019) * *$ \\
\hline $8.0 \%$ & $287.6 \%$ & $(0.000) * * *$ \\
\hline $5.2 \%$ & $7.9 \%$ & $(0.139)$ \\
\hline $4.5 \%$ & $11.2 \%$ & $(0.002) * * *$ \\
\hline
\end{tabular}

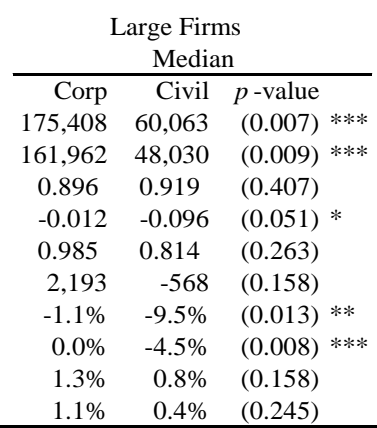

Standard Deviation

\begin{tabular}{|c|c|c|c|}
\hline Corp & Civil & $p$-value & \\
\hline 200,825 & 358,878 & $(0.049)$ & $* *$ \\
\hline 213,720 & 257,834 & $(0.519)$ & \\
\hline 0.155 & 1.062 & $(0.000)$ & $* * *$ \\
\hline 0.230 & 1.038 & $(0.000)$ & $* * *$ \\
\hline 0.733 & 0.421 & $(0.046)$ & $* *$ \\
\hline 23,138 & 76,213 & $(0.000)$ & $* * *$ \\
\hline $12.2 \%$ & $33.8 \%$ & $(0.001)$ & $* * *$ \\
\hline $6.3 \%$ & $58.2 \%$ & $(0.000)$ & $* * *$ \\
\hline $3.8 \%$ & $8.8 \%$ & $(0.006)$ & $* * *$ \\
\hline $1.8 \%$ & $47.7 \%$ & $(0.000)$ & $* * *$ \\
\hline
\end{tabular}

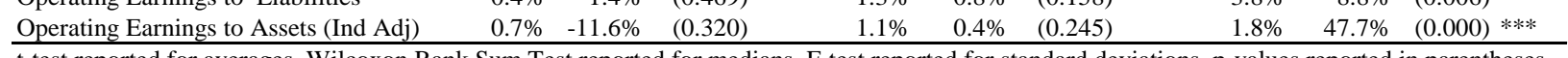
t-test reported for averages, Wilcoxon Rank Sum Test reported for medians, F-test reported for standard deviations, p-values reported in parentheses. $* * *, * *$, and * indicate that the parameter estimate is significantly different from 0 at the $1 \%, 5 \%$, and $10 \%$ level, respectively. 
The univariate analysis of the partitioned database indicates several interesting results. Smaller firms filing under the new system experience a larger decline in assets $(-26.5 \%$ vs. $-3.8 \%, p$-value 0.013$)$ and have poorer operating earnings $(-6.6 \%$ vs. $0.9 \%, p$-value 0.003$)$ and net income relative to assets $(-19.6 \%$ vs. $-0.5 \%, p$-value 0.003). All are indications of a firm trying to stave off bankruptcy and which suggest the new form of bankruptcy did not have the desired impact on smaller firms. Retained earnings are also less for firms filing under the new system (- ¥4,969 million vs. ¥262 million, $p$-value 0.017 ).

Large firms filing under the Reorganization Act are significantly larger than the large firms filing under the Rehabilitation Act in terms of both Assets (¥199,320 million vs. ¥57,156 million, $p$-value 0.001) and Sales (¥179,560 vs. $¥ 43,726, p$-value 0.001 ). Operating earnings are slightly smaller but are not statistically significant $(0.8 \%$ vs. $1.3 \%, p$-value 0.329$)$ but the ratio of net income to total assets is significant $(0.0 \%$ vs. $-3.5 \%, p$-value 0.048). The percentage of shares held by financial institutions is also larger for firms which filed under the old system (35\% vs. $23.6 \%, p$-value 0.018). None of the reported statistics suggest that the introduction of the Rehabilitation improved the quality of the firms filing, rather they indicate that weaker firms seem to be using the new system. This is particularly true of the small firms, for which the law was intended.

\section{Regression Analysis}

A multivariate logistic regression is used to capture firm characteristics which make filing under the Rehabilitation law more likely. Four regression models are shown in Table 5. The dependent variable (CIVIL) is a dummy variable which takes the value of 1 if the firm filed under the Rehabilitation law, 0 if not. The regression estimates the model:

$$
\begin{aligned}
& \mathrm{P}\left(\text { CIVIL }_{i}\right)=a+a_{1} \text { LNASSETS }_{i}+a_{2} \text { LNSALES }_{i}+a_{3} \text { LEV }_{i}+a_{4} \text { FINPERCENT }_{i}+a_{5} \text { CURRENT }_{i}+ \\
& a_{6} \text { EBITTL }_{i}+a_{7} \text { DASSETS }_{i}+e_{i}
\end{aligned}
$$

where P(CIVIL) is the logit probability of CIVIL which equals 1 if the firm files under the Civil Rehabilitation Law, 0 otherwise, for filing $i$. LNASSETS is the log of the firm's assets in either year -1 or -2 . LNSALES is the log of the firm's sales in either year -1 or -2. FINPERCENT is the percentage of the filing firm's common stock held by financial institutions. CURRENT is the firm's Current Ratio, defined as the firm's Current Assets divided by its Current Liabilities. EBITTL is the firm's operating income defined as the ratio of Net Sales less Cost of Goods Sold, and Selling and General and Administrative Expenses divided by Total Liabilities in either year -1 or -2. DASSETS is the change in assets that occurred from year -3 to the later of either year -1 or year -2 . The Small Firms are the smallest half of each filing type. Large firms are the largest half of each firm of each filing type.

\begin{tabular}{|c|c|c|c|c|c|c|}
\hline & & & Small Fi & rms & Larg & Firms \\
\hline & 1 & 2 & 3 & $\overline{4}$ & 5 & 6 \\
\hline INTERCEPT & 3.34 & 2.18 & 7.36 & 2.05 & $48.77 * *$ & $17.46 * *$ \\
\hline & $(0.251)$ & $(0.341)$ & $(0.246)$ & $(0.721)$ & $(0.025)$ & (0.030) \\
\hline LNASS & $\begin{array}{r}-0.316 \\
(0.375)\end{array}$ & & $\begin{array}{r}-0.663 \\
(0.288)\end{array}$ & & $\begin{array}{l}-5.525 * * \\
(0.019)\end{array}$ & \\
\hline LNSALES & & $\begin{array}{r}-0.305 \\
(0.184)\end{array}$ & & $\begin{array}{r}-0.244 \\
(0.696)\end{array}$ & & $\begin{array}{l}-1.725 * * \\
(0.022)\end{array}$ \\
\hline LEV & $\begin{array}{r}-0.289 \\
(0.903)\end{array}$ & $\begin{array}{r}0.899 \\
(0.501)\end{array}$ & $\begin{array}{r}-1.243 \\
(0.410)\end{array}$ & & $\begin{array}{l}8.558 * * \\
(0.044)\end{array}$ & \\
\hline FINPERCENT & $\begin{array}{r}0.378 \\
(0.923)\end{array}$ & & & & & \\
\hline CURRENT & $\begin{array}{l}-0.209 \\
(0.785)\end{array}$ & & $\begin{array}{r}-0.668 \\
(0.359)\end{array}$ & $\begin{array}{r}-0.387 \\
(0.479)\end{array}$ & $\begin{array}{c}7.923 * * \\
(0.045)\end{array}$ & $\begin{array}{r}1.623 \\
(0.248)\end{array}$ \\
\hline EBITTL & $\begin{array}{l}-15.78 * * \\
(0.040)\end{array}$ & $\begin{array}{l}-11.27 * \\
(0.063)\end{array}$ & $\begin{array}{l}-28.70 * * \\
(0.020)\end{array}$ & $\begin{array}{l}-23.87 * * \\
(0.018)\end{array}$ & $\begin{array}{l}133.71 * * \\
(0.026)\end{array}$ & $\begin{array}{l}36.77 \text { ** } \\
(0.039)\end{array}$ \\
\hline DASSETS & $\begin{array}{l}-5.17 * \\
(0.062)\end{array}$ & $\begin{array}{l}-4.60 * * \\
(0.036)\end{array}$ & $\begin{array}{r}-8.70 \\
(0.113)\end{array}$ & $\begin{array}{l}-6.22 * \\
(0.100)\end{array}$ & $\begin{array}{l}-15.91 * \\
(0.060)\end{array}$ & $\begin{array}{c}-9.97 * \\
(0.081)\end{array}$ \\
\hline Adjusted R-square & 0.3193 & 0.2971 & 0.4656 & 0.4288 & 0.7165 & 0.4648 \\
\hline $\mathrm{N}$ & 51 & 60 & 30 & 30 & 30 & 30 \\
\hline
\end{tabular}

Table 5: Regression Results 
Regression models 1 and 2 examine all filings in the database. The coefficient measuring operating earnings (EBITTL) and the change in assets (DASSETS) are significant and negative indicating that, operating earnings are worse for firms filing Rehabilitation and that firms filing Rehabilitation underwent a greater decline in assets prior to filing, consistent with the results in the univariate section. Regression models 3 and 4 examine the smaller firms in the data set. The coefficient for operating earnings is negative and significant indicating that firms which filed under Rehabilitation had poorer earnings and were therefore poorer candidates for reorganization. The change in assets in models 3 and 4 are both negative and in model 4 are significant. It is nearly significant in model 3 as well. This suggests that firms are not choosing to file sooner but are waiting longer.

Models 5 and 6 examine large firms. Larger firms are more likely to file Reorganization. Firms with a larger Liabilities to Assets ratio (LEV) are more likely to file under the Rehabilitation law. A higher current ratio also increases the probability of filing under the new law. Also, firms with greater declines in assets are also more likely to file under the Rehabilitation law, an indication that firms are trying to delay filing bankruptcy longer under the new law. Interestingly, operating earnings are higher for large firms filing Rehabilitation. This is the opposite result from the findings of small firms and suggests that large firms filing under the new system make better candidates for reorganization. Such a result is consistent with management selling off less profitable or less important assets.

\section{CONCLUSION}

In April of 2000, Japan introduced Civil Rehabilitation, a new form of bankruptcy, and eliminated Composition, an older form of bankruptcy. Prior to this date, the Japanese bankruptcy reorganization system for large firms had no "debtor-in possession" (DIP) type protections for filing management at large firms. A primary argument for DIP protections is that they reduce the personal costs endured by management and hence result in less delay before filing allowing the court and creditors to address the firm's problems before they are too severe. The impact of the introduction of Civil Rehabilitation is the subject of this paper.

Rehabilitation resulted in several important changes to the characteristics of the filing firms. Soon after its introduction all sizes of firms were choosing to file under the new system. That is, it became the de facto form of bankruptcy filing for all firms. One intention of the new law was to encourage firms to file sooner after they encounter financial distress. However, the typical small firm filing under the new law is in poorer financial condition, when measured in terms of profitability and capital structure metrics and has sold off a greater percentage of its assets, an indication that the new law was not accomplishing its stated goal. This result is consistent with managers who want to stave off bankruptcy for as long as possible and are selling off the more profitable assets of the firm. Larger firms, while also enduring a greater decline in assets are more profitable prior to filing. This suggests that they made better candidates for reorganization after the law was enacted, but still struggle to avoid bankruptcy. Hence, the Civil Rehabilitation Act improved the Japanese bankruptcy system for large firms but worsened it for small firms.

\section{AUTHOR INFORMATION}

Gregory R. Stone is an Assistant Professor of Finance at the University of Nevada, Reno. He is Director of the Master of Science in Finance Program and holds CFA and FRM Charters. Dr. Stone earned his Ph.D. at the University of Hawaii at Manoa where he was an East-West Center Degree Fellow and holds masters degrees from the Colorado School of Mines and the École Nationale Superérieure du Pétrole et des Moteurs (ENSPM). Dr. Stone has previously worked for the investment banking firm Kirkpatrick Energy Associates, Inc., and for BP Exploration.

\footnotetext{
${ }^{1}$ Minji Saiseihō (Civil rehabilitation act), Law No. 225 of 1999 and Wagihō (Composition act), Law No. 72 of 1922 , respectively.

${ }^{2}$ Kaisha Kōseihō (Corporate reorganization act), Law No. 172 of 1952. Kaisha Seiri (Corporate arrangement act) Law No. 72 of 1938. Shirata (2005) reports that only $0.4 \%$ of firms filed under the Corporate arrangement act.

${ }^{3} \mathrm{Xu}$ (2004) finds that "in practice, all managers depart after the commencement" of Reorganization. Since Japan's system of keiretsu results in close firm monitoring by those with a financial interest in the firm, prior to filing. The monitoring process allows those with a financial interest in the firm, to decide whether the firm's poor performance is attributable to management or
} 
not, suggesting that mandatory replacement of managers is unwarranted. Lang and Stulz (1992), Khanna and Poulsen (1995), and Denis and Denis (1995) suggest that the causes of bankruptcy are primarily systematic rather than the fault of management.

${ }^{4}$ Under the Composition Law, the court's involvement ended with the acceptance of the reorganization plan. Because Japan has an overcrowded court system, a long delay is typical before a hearing, debtors often use the system to their advantage by filing under the Composition Law, then failing to comply with the plan, which results in the creditor having to refile bankruptcy again and repeat the process. Reorganization cases can be stretched out for up to 10 years or more this way. Creditors frequently preferred liquidation so as to get a certain value immediately rather than face going through a Composition filing again. The new law, Civil Rehabilitation, allows creditors to enforce their rights while still under court supervision (Source: Arthur J. Alexander (2000)).

${ }^{5}$ Banks owned between $0.1 \%$ to $58.9 \%$ of the firms filing under the two bankruptcy systems with the median equity ownership being $29.7 \%$ for Corporate Reorganization firms and $19.8 \%$ for Civil Rehabilitation filings.

${ }^{6} \mathrm{Xu}$ (2004) reports that the average duration of a corporate reorganization filing was 2.2 years while the average Civil Rehabilitation filing was only 0.6 years. Since Corporate reorganization uses a trustee and civil rehabilitation allows for management to remain, this is consistent with the position that management wants out of bankruptcy as quickly as possible, even if it does not result in optimal reorganization (see e.g., Denis and Rodger (2005) and Rhee and Stone (2007).

${ }^{7}$ Comparisons of the standard deviations when the, object of consideration is not normalized can be misleading as larger firms likely have a larger standard deviations. To address this issue, the coefficient of variation is used. The coefficient of variation for Assets is 1.59 for Reorganization and 1.49 for Rehabilitation, a difference of $7 \%$. The coefficient of variation for Sales, another proxy for size, is 1.55 for Reorganization and 1.58 for Rehabilitation, a difference of $2 \%$.

\section{REFERENCES}

1. Adler, B., V. Capkun and L. Weiss, 2005, Theory and Evidence on the Bankruptcy Initiation Problem, working paper.

2. Altman, E., 1993, Evaluating the Chapter 11 Bankruptcy Reorganization Process, Columbia Business Law Review 1-25.

3. Alexander, A., 2000, Business Failures Rising in Japan as New Bankruptcy Law takes Effect, Japan Economic Institute 22, 2000.

4. Aoki, M., and H. Patrick, 1994, The Japanese Main Bank System Its Relevance for Developing and Transforming Economics, Oxford University Press.

5. Bebchuk, L., and C. Howard, Bargaining and the Division of Value in Corporate Reorganization, Journal of Law, Economics, and Organization, 1992, 8, pp. 523-546.

6. Berkovitch, E., R. Israel and J. Zender, 1998, The Design of Bankruptcy Law: a Case for Management Bias in Bankruptcy Reorganizations, Journal of Financial and Quantitative Analysis 33, 441-464.

7. Berlin, M., K. John and A. Saunders, 1996, Bank Equity Stakes in Borrowing Firms and Financial Distress, Review of Financial Studies 9, 889-919.

8. Bradley, M., and M. Rosenzweig, 1992, The Untenable Case for Chapter 11, Yale Law Review 101, 10431095.

9. Bris, A., 2006, working paper

10. Denis, D., and D. Denis, 1995, Performance Changes following Top Management Dismissals Journal of Finance 50, 1029-1057.

11. Denis, D., and K. Rodgers, 2007. Reorganization in Chapter 11. Journal of Financial and Quantitative Analysis 42, 101-118.

12. Easterbrook, F., 1990, Is Corporate Bankruptcy Efficient?, Journal of Financial Economics 27, 411-417.

13. Eisenberg, T., and S. Tagashira, 1994, Should We Abolish Chapter 11? The Evidence from Japan, Journal of Legal Studies, University of Chicago Press 23, 111-157.

14. Gertner, R., and D. Scharfstein, 1991, A Theory of Workouts and the Effects of Reorganization Law, Journal of Finance 46, 1189-1222.

15. Gilson, S., and M. Vetsuypens, 1993, CEO Compensation in Financially Distressed Firms: An Empirical Analysis, Journal of Finance 43, 425-458.

16. Helwege, J., 1999, How Long do Junk Bonds Spend in Default?, Journal of Finance 54, 341-357.

17. Helwege, J., and F. Packer, 2003, Determinants of the Choice of Bankruptcy Procedure in Japan, Journal of Financial Intermediation 12, 96-120.

18. Hotchkiss, E., 1995, Postbankruptcy Performance and Management Turnover, Journal of Finance 50, 3-21. 
19. Hoshi, T., A. Kashyap, and D. Scharfstein, 1990, The Role of Banks in Reducing the Costs of Financial Distress in Japan, Journal of Financial Economics 27, 67-88.

20. Jensen, M., 1989, Active investors, LBOs, and the privatization of bankruptcy, Journal of Applied Corporate Finance 2, 35-44.

21. Kang, J., and A. Shivdasni, 1995, Firm Performance, Corporate Governance, and Top Executive Turnover in Japan, Journal of Financial Economics 38, 29-58.

22. Kaplan, S., and B. Minton, 1994, Appointments of Outsiders to Japanese Boards: Determinants and Implications for Managers, Journal of Financial Economics 36, 225-257.

23. Khanna, N., and A. Poulsen, 1995, Managers of Financially Distressed Firms: Villains or Scapegoats? Journal of Finance 50, 919-940.

24. Lang, L., and R. Stulz, 1992, Contagion and Competitive Intra-industry Effects of Bankruptcy Announcements, Journal of Financial Economics 32, 45-60.

25. Mooradian, R., 1994, The effect of bankruptcy protection on investment: Chapter 11 as a screening device, Journal of Finance 49, 1403-1430.

26. Morck, R., and M. Nakamura, 1999, Banks and Corporate Control in Japan, Journal of Finance 54, 319339.

27. Prowse, S., 1990, Institutional Investment Patterns and Corporate Financial Behavior in the United States and Japan, Journal of Financial Economics 27, 43-66.

28. Prowse, S., 1992, The Structure of Corporate Ownership in Japan, Journal of Finance 47, 1121-1140.

29. Schumpeter, J., 1942, Capitalism, Socialism and Democracy, New York: Harper \& Row, 1942, $381-384$.

30. Sheard, P., 1994, Main Banks and the Governance of Financial Distress, The Japanese Main Bank System. Oxford: Oxford University Press, 188-230.

31. Shirata, Y., 2005, Japanese Bankruptcy Presentation, University of Hawaii.

32. Rhee, S.G., and Stone, G., 2009, Why do CEOs file bankruptcy in Delaware? An Agency Theory Perspective of Forum Shopping, working paper.

33. Suzuki, S., and R. Wright, 1985, Financial Structure and Bankruptcy Risk in Japan, Journal of International Business Studies 16, 97-110.

34. Thorburn, K., 2000, Bankruptcy Auctions: Costs, Debt Recovery, and Firm Survival, Journal of Financial Economics 58, 337-368.

35. White, M., 1994, Corporate Bankruptcy as a Filtering Device: Chapter 11 Reorganizations and Out of Court Debt Restructurings, Journal of Law, Economics, and Organization 10, 286-295.

36. Wruck, K., 1990, Financial Distress, Reorganization, and Organizational Efficiency, Journal of Financial Economics 27, 419-44.

37. Xu, P., 2004, Bankruptcy Resolution in Japan: Civil Rehabilitation vs. Corporate Reorganization, RIETI Discussion Paper Series 04-E-010, 1-46. 
NOTES 